H.ydrocarbons in the Non-Urban Atmosphere: Analysis, Ambient Concentrations and Impact on the Chemistry of the

Atmosphere ${ }^{\dagger}$

J. RUDOLPH and A. KHEOIM

Instrivut für Chemie 3: Atmosphàrische Chemie der Kernforschungsanlage Jülich GmbH, Pastach 1913, D-5170 Jülith, FRG

(Received Januery 22. 1985)

The roit of hydrocarbons for the inemistry of the atnusphere outside of hesvily poffuted urben or industriat ureas is not yet fullt, understood. One of the resusuns is

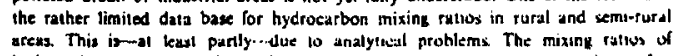

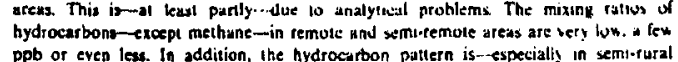

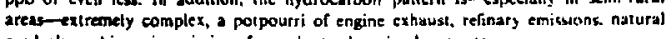
gas leak age, biogentic emisssions from plants, decoving leaves ele.

In the pall lew years we have developed gas thrimalographic lechnses fins the outside polluted areass. The resulls of these measurements, thus that thete nun.

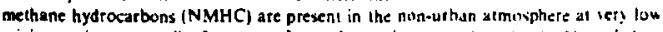

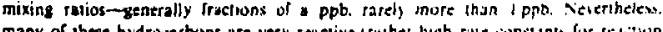

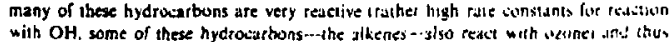
are of considerable importance for the chemistr? of the stminphure

In this paper we present atmospheric measuetements af some nun-mett.une

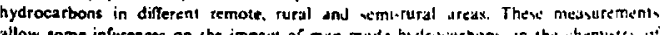

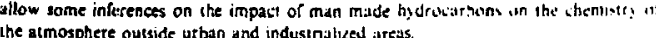

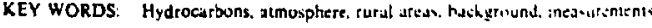

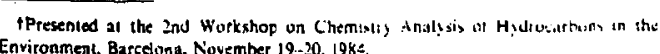


HYDROCARBONS IN NON-URBAN ATMOSPBER TABLE I

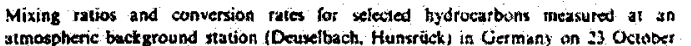

The important role of non-methane hydrocartions for the photwchemical reaction cycles in urban and industrialized areas has long been recognized. As far as aon-urban areas are concerned methane is often the only hydrocarbon compound which is considered as important for the chemistry of the atmosphere. However, since a

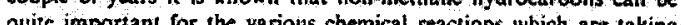

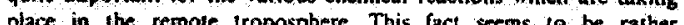
surprising if we have a look at the mixing ratios of some of the different hydrocarbons which can be found in rural continental areas. Table I presents the mixing ratios of a number of hydrocasbons measured at a remote rural site in continental Germany If we compare the mixing ratio of $\mathrm{CH}_{4}$ with that of the other hydrocarbons. we see that methane is roughly three orders of magnitude more abundant than each of the other hydrocarbons. This indeed suggests that methane might be the oniy hydrocarbon compound which is important for the chemistry of the atmosphere. At a closer inspection this conclusion however seems premantre. The atmospheric reaction chain of hydrocarbon oxidation starts mainly with the attack of an $\mathrm{OH}$ radical:

$$
\mathrm{RH}+\mathrm{OH} \stackrel{\mathrm{Kam}}{\rightarrow} \mathrm{R}+\mathrm{H}_{2} \mathrm{O} .
$$

The conversion rate for a given hydrocarbon in the atmosphere then can be written as:

$$
r_{\mathrm{OH}}=k_{\mathrm{OH}}[\mathrm{RH}][\mathrm{OH}] \text {. }
$$

From this it is evident that for a comparison of the different hydrocarbons with respect to their participation in atmospheric the atmospheric concentrations of the individual hytarocartons if we want to compare their almospheric reaction rate. Therfore we included in Table $I$ the product of reaction rate constant and atmospheric mixing ratio 10 allow a direct comparison of the different hydrocarbons. We can see that the turnover rates for the

\begin{tabular}{|c|c|c|c|c|}
\hline Compound & $\begin{array}{c}\text { Mixing ratio } \\
\text { (ppb) }\end{array}$ & 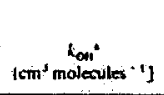 & 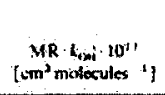 & 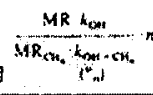 \\
\hline 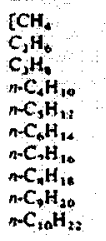 & $\begin{array}{c}8740 \\
1.35 \\
0.72 \\
0.54 \\
0.14 \\
0.051 \\
0.044 \\
0.014 \\
<0.01 \\
<0.01\end{array}$ & 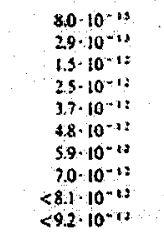 & 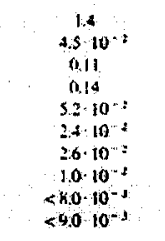 & $\begin{array}{c}100 \\
0.4 \\
24 \\
010 \\
19 \\
10 \\
13 \\
6 \\
<5 \\
<6\end{array}$ \\
\hline $\begin{array}{l}i-C_{C} H_{10} \\
i-C_{3} H_{72}\end{array}$ & $\frac{0.22}{0.25}$ & $\begin{array}{l}2.4 \cdot 10^{-12} \\
4.6 \cdot 10^{-12}\end{array}$ & $\begin{array}{c}5.310^{-2} \\
0.12\end{array}$ & 45 \\
\hline $\begin{array}{l}\mathrm{C}_{3} \mathrm{H}_{4} \\
\mathrm{C}_{3} \mathrm{H}_{6} \\
\mathrm{C}_{2} \mathrm{H}_{2} \\
\mathrm{C}_{6} \mathrm{H}_{6} \\
\mathrm{C}_{3} \mathrm{H}_{6} \mathrm{CH}_{3}\end{array}$ & $\begin{array}{l}0.00 \\
0.10 \\
0.59 \\
0.12 \\
0.18\end{array}$ & $\begin{array}{l}8.1 \cdot 10^{\prime 11} \\
1.5 \cdot 10^{-11} \\
1.6 \cdot 10^{-11} \\
1,2 \cdot 10^{-13} \\
6 \cdot 10^{-12}\end{array}$ & 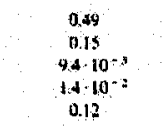 & $\begin{array}{c}70 \\
3 z \\
1 \\
6 \\
43\end{array}$ \\
\hline $\begin{array}{l}m \text {-Xylol } \\
m-X \text { yllot }\end{array}$ & 0.04 & $1.5 \cdot 10^{-11}$ & $a(n-0.1$ & 34.57 \\
\hline inxylal & 0,02 & $1.4 \cdot 10^{-31}$ & $30 \cdot 10^{\circ}=$ & 19 \\
\hline$C_{4} H_{3} C_{2} H_{3}$ & 0.05 & $3.5 \cdot 10^{-12}$ & $3.8 \times 19^{-2}$ & $\because 2$ \\
\hline
\end{tabular}
$1933,14: 30 \mathrm{~h}$.

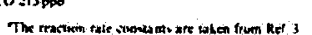

various hydrocasbons are significantly lawer than for methane bu in total the NMHC conversion rates exceed that of methanc. If wo estimate the tumover rates for the difierent hydrocarbons in terms of carbon atoms instead of molecules (that is we have to multuply the atmospheric conversion rates for each individual hydrocarbon with the number of earbon aloms in this empound) we can see that the 
1. RUDOLPH AND A. KHEDIM

air sample contained $210 \mathrm{ppb} \mathrm{CO}$, a value which is comparable to $\mathrm{CO}$ mixing ratios which were reported by Sehmidt et al. ${ }^{\prime}$ in the free troposphere over North America.

It is obvious that such simple estimates as above do not give an exact picture of the actual impact of the various NHMCs on the chemistry of the atmosphere. The intermediate products of the hydrocarbon oxidation chains le.g. aldehydes, ketones, alkylperoxides, etc) may be removed from the aimosphere by wet or dry deposition. On the other side most of the intemediate products of deposition. On the other side most of the intermediate products of NHMC oxidation are considerably more complex. than the products of methane oxidation and thus can open new pathways in the chemistry of the atmosphere (eng. Duco en al. ). From these consider ancons is evident that for a thorough from thase conding of the chemistry of the almosphere in remote or semi-remote areas we need inforis carbons. Unfortunately the existing data base is far from being

There are a few measurements of light hydrocarbons in the remote marine atmosphere, data from the interfacial region between urban polluted areas and the remote unpolhuted atmosphere are nearly completely missing. In the past few years we made a number of measurements of light and medlan molecular weight hydrocarbons in the armosphere outside pollued areas to this paper we will measurements in renote and semi-remote

\section{MEASUREMENT TECHNIQUES}

The air samples are collected in evacualed. carefully pletreated stainless steel containers with metal bellow valves. The samples are afterwards analyzed in the laboratory by different gas chromatographic techniques. The hydrocarbons are preconcentrated from typically $0.5-2 \mathrm{dm}^{3}$ of air (STP) on solid sorbents (porous glass beads. porous siliea, carbosieve) at subambient remperatures. The light hydrocarbons $\left(C,-C_{3}\right)$ are separated on packed stainless steel columns (inner diameter $0.8 \mathrm{~mm}$. length $5-10 \mathrm{~m}$ ). As column packings porous silica. modined porous silica (Porasil C-n-octane) or porous polymers (Parapak $Q$ or $Q S$ ) are used. The choice of the
HYDROCARBONS IN NON-URBAN ATMOSPHERE

stationary. phase depends in each case on the compounds on which our main interest is focussed. The hydrocarbons with more than 5 carbon atoms are separated on glass or quartz capillary column with stationary : phases of low polarity (OV-101. SE-30. DB 1). For hydrocarbon measurements name tonisation- or photoionisation detectors $(10.2 \mathrm{eV})$ are used. With thame innisation detection the lower limit of detection (36) is typically 10-20 ppt in a $1 \mathrm{dm}^{3}$ (STP) air sample for packed columns and S-10 ppt with capillary colurns. Cormpounds with high photolonisation cross-sechions such as aromaties and most of the aikenes have between a factor of 3 and 20 lower detection limits with a photoionisation detestor $(10.2 \mathrm{eV}$ lamp compared to a flame ionisation detector. The precision of the measurements is generally betler than $15 \%$ typically between $5^{\circ}$ and $10 \%$.

\section{HYDROCARBONS IN THE REMOTE AND} SEMI-REMOTE CONTINENTAL ATMOSPHERE

If we consider the large number of diflerent hydrocarbons which are emitted from various industtial, urban and natural sources ${ }^{2}$ and the rather short atmospheric resideoce times for most of the hydrocarbons of a few days or even less ${ }^{*}$ we can expect a considerable variability with time location meteorological conditions etc. Thus it will be extremely dificult 10 define peneral "continental background" values for hydrocarbon mixing matios. Instead of trying 10 do so we will present some resuls we obuined from several measurement weries pres home restls we oblos. which dify deters the atmosphere over remote or semi-remote continental areas.

In Figure 1 he resuls of some In figure i the resuls of some secced mearements are shown

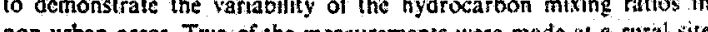
nent near Jalich bus whe the wind rrom dinere Fores a 1280 ced a Furing al $1280 \mathrm{~m}$ allude which was above the bor during sampling Also included for companson are the resuls lis

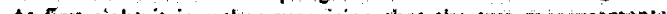




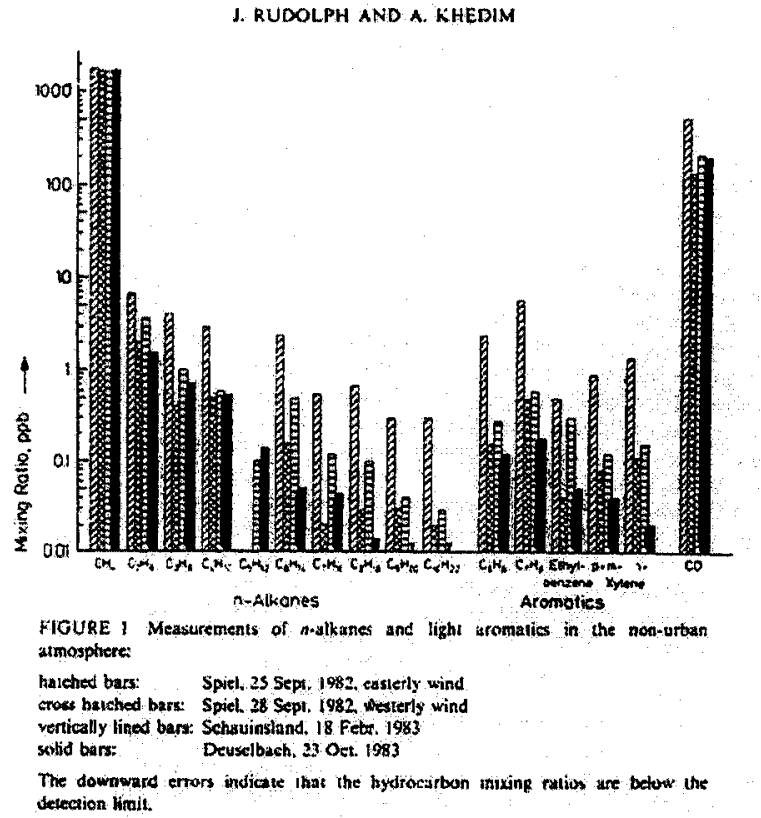

Spiel (near Jülich) show such large differences in hydrocarbon mixing ratios-up to an order of magnitude for some compounds. However the sampling industrialized and denty populat an $30-100 \mathrm{~km}$ east of $5 p$ iel phereas ther is area for more than $200 \mathrm{~km}$ west of Spiel This shows that thanesor can strongly influence the hydrocaron. mixing ratios in rumal areas
HYDROCARBONS IN NON.LRHAN ATMOSPHERE

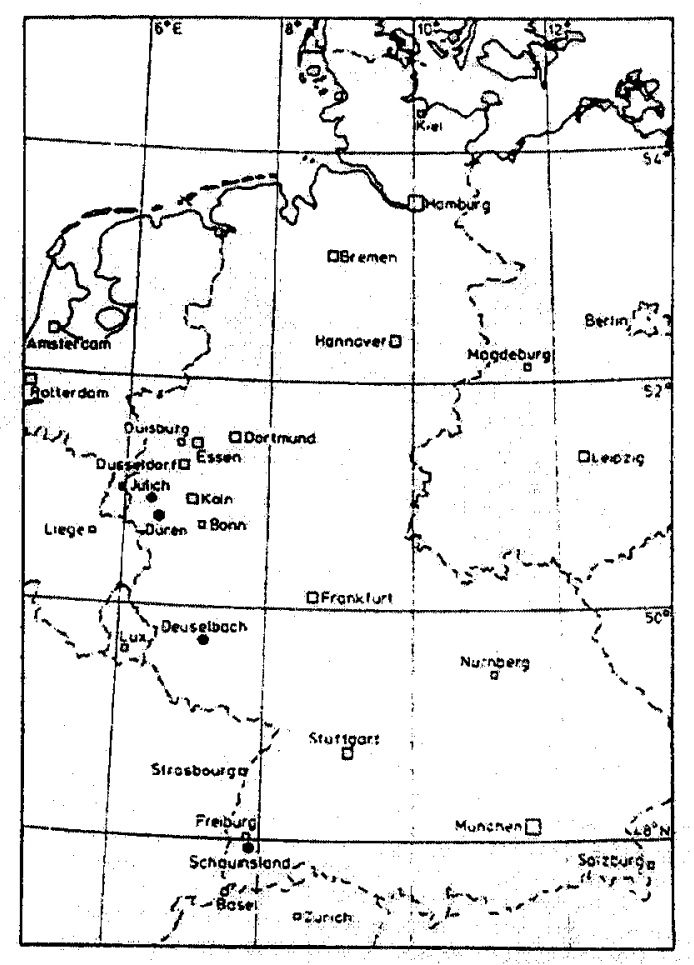

FTOURE 2 Map showing the sumpling locutions firt mesisuremenes of hydrixarhons 
S. RUDOLPH AND A. KHEDIM

and we may expect extreme variations in the hydrocarbon mixing ratios even outside urban areas.

Never theless we observe some features in the hydrocarbon profiles which deserve interest. For the $n$-alkanes the atmospheric mixing rattos show a considerable decrease with increasing carbon number. We also observe that the diferences in mixing ralios between the different samples seem to increase with increasing carbon number. e.g. for $\mathrm{CH}_{4}$ the variation is only a few percent, $\mathrm{Cor}_{2} \mathrm{H}_{6}$ the highest and lowest mixing ratios differ by a factor of about 4 and for $n$ $\mathrm{C}_{8} \mathrm{H}_{18}$ this factor is nearly $\mathrm{SO}$. Similar observalions can be made for the light aromatics, the benzene mixing ratios in Figure I vary about a factor of 20, the o-xylene values more than a factor of 50 . This indicates that hydrocarbons of lower reactivity, e.g. ethane, show much less pronounced variations in their almospheric mixing ratios than highly reactive species such as xylene. Moreover it seems that the air samples with the largest hydrocarbon mixing ratios show the least pronounced difference between the hydrocarbons of different reactivity, e.g. for sample No. I with $6.8 \mathrm{ppb}$ of $\mathrm{C}_{2} \mathrm{H}_{6}$ the ratio $\mathrm{C}_{2} \mathrm{H}_{6} / \mathrm{C}_{3} \mathrm{H}_{18}$ is about 10 , for sample No. 4 with only $1.55 \mathrm{ppb}$ of $\mathrm{C}_{2} \mathrm{H}_{6}$ this ratio amounts to about 100 . Similar observations can be made for the light aromatic species.

This suggests that dilution as weil imporlant factors which govern the hydrocarbon mixing ratios in remote continental areas. However, it would be premature to draw such conclusions from only 4 measurements.

Thus we will look at the malter in some more detail. Table II shows the results of several measurements which were made in March 1984 in a semi-rural area near Düren (see Figure 2). From the rather high mixing ratios of predominantly made-made species such as the light aromatic hydrocarbons or $\mathrm{CO}$ and $\mathrm{C}_{2} \mathrm{H}_{2}$ it is evident that the sampled air is substantially influenced by strong anthropogenic hydrocarbon sources. Indeed the relative pattern of the hydrocarbons is very similar to results reported for sorae major cities in the U.S..' however the absolute mixing ratios listed in Table II are generally somewhat lower. We can compare these data from areas with significant polsution with measurements from a more remote site in continental Europe. In Table III the results of three series of measurements al "background station" (Deuselbach) are shown. Each of the series consisted of at least 6 measurements. These
HYDROCARBONS IN NON-LRBAN ATMOSPHERE

TABLE U

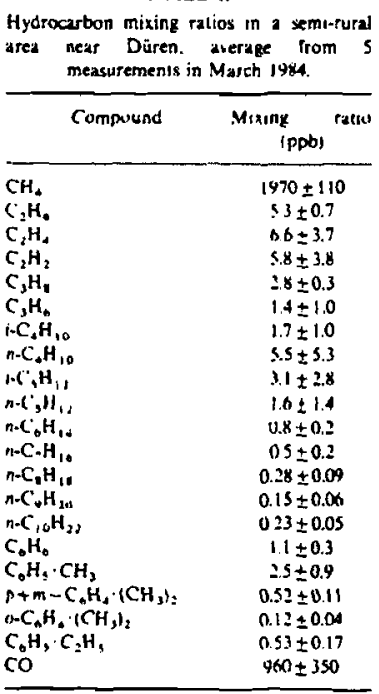

mixing ratios are rather low, especially the alkyl aromatics aro . decrease between polluted and remote areas is more pronounced for the more reactive species, that is the pittern of the trace gas mixing ratio changes systematically as we go from polluted areas to remore locations: the abundance of a given hydrocarton compound do creases the more rapidly the more reactive the conposund is.

There is another point which deserves interest. the more reactio hydrocarbons such as propene or xylene shou cunsiderably higher mixing ratios in October than in May-June. whereas the more stable species such as $\mathrm{C}_{2} \mathrm{H}_{0,} \mathrm{C}_{2} \mathrm{H}_{2}$ or $\mathrm{CO}$ or even $\mathrm{C}_{n} \mathrm{H}_{0}$ remain ressentially unchanged. This is just what would tee expected if phorochomial 
1. RUDOLPH AND A. KHEDIM

TABLE III

Averape hydrocarbon mixing ratios from theer series of measurements an a remole Continenial site in West Germany (Deuselbach)

Volume mixing ratios (ppb)

\begin{tabular}{|c|c|c|c|}
\hline \multirow[b]{2}{*}{ Compound } & \multicolumn{3}{|c|}{ Volume mixing ratios (ppb) } \\
\hline & 18-20 May 198 : & 3-7 June 1983 & 22-23 ${ }_{1983}^{\text {October }}$ \\
\hline $\mathrm{CH}_{4}$ & $1740 \pm 23$ & $1740 \pm 37$ & $1740 \pm 10$ \\
\hline $\mathrm{C}_{2} \mathrm{H}_{4}$ & $2.33 \pm 0.38$ & $1.98 \pm 0.18$ & $1.84 \pm 0.22$ \\
\hline $\mathrm{C}_{2} \mathrm{H}_{4}$ & $0.45 \pm 0.14$ & $0.47 \pm 0.32$ & $0.71 \pm 0.40$ \\
\hline $\mathrm{C}_{2} \mathrm{H}_{2}$ & $0.55 \pm 0.18$ & $0.52 \pm 0.13$ & $0.64 \pm 0.20$ \\
\hline $\mathrm{C}, \mathrm{H}$, & $0.54 \pm 0.10$ & $0.40 \pm 0.13$ & $0.86 \pm 0.12$ \\
\hline$c, H_{0}$ & $0.08+0.03$ & $0.07+0.03$ & $0.33 \pm 0.24$ \\
\hline 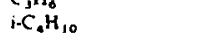 & $0.20 \pm 0.07$ & $0.17+0.11$ & $0.28+0.10$ \\
\hline$n-C_{1} H_{10}$ & $0.40 \pm 0.15$ & $0.39 \pm 0.29$ & $0.71 \pm 0.28$ \\
\hline i-C, $\mathrm{H}_{13}$ & $0.27 \pm 015$ & $0.31 \pm 0.20$ & $0.37 \pm 0.22$ \\
\hline $\begin{array}{l}n_{n-C, H_{12}} \\
n-H_{12}\end{array}$ & $0.12 \pm 0.05$ & $0.16 \pm 0.13$ & $0.22 \pm 0.08$ \\
\hline nat & $0.05 \pm 0.02$ & $0.08 \pm 0.07$ & $0.10 \pm 3.05$ \\
\hline $\mathrm{C}_{6} \mathrm{H}_{4} \mathrm{H}_{42}$ & $\begin{array}{l}0.03 \pm 0.02 \\
0.10 \pm 0.04\end{array}$ & $\begin{array}{l}0.15 \pm 0.07 \\
0.07\end{array}$ & $0.12 \pm 0.04$ \\
\hline $\mathrm{C}_{6} \mathrm{H}_{3} \cdot \mathrm{CH}_{3}$ & $0.11 \pm 0.06$ & $0.18 \pm 0.12$ & $0.22 \pm 0.09$ \\
\hline$p+m-C_{3} \cdot H_{0} \cdot \mathrm{CH}_{N}$ & $0.02+0.01$ & $0.03 \pm 0.02$ & $0.06 \pm 0.03$ \\
\hline $\mathrm{O}-\mathrm{C}_{\mathrm{C}} \cdot \mathrm{CH}_{3}$ & $0.02+0.01$ & $0.02+0.01$ & $0.04 \pm 0.01$ \\
\hline $\mathrm{C}_{0} \mathrm{H}, \mathrm{C}_{2} \mathrm{H}$ & $0.04 \pm 0.02$ & $0.06 \pm 0.05$ & $0.07 \pm 0.04$ \\
\hline $\mathrm{co}$ & $340 \pm 28$ & $227 \pm 27$ & $213 \pm 25$ \\
\hline
\end{tabular}

oxidation is responsible for the above mentioned difference in the relative abundano of the hydrocarbons between the urban ind the remote continental atmosphere: the average $\mathrm{OH}$ radical conent

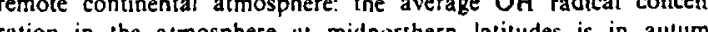
ration in he almo almere with $\mathrm{OH}$ low with Or radicals such as the phorochemical remolal or hydrocarbons are bound to be substanially less pronounced in Ocheber than in Maymlune. However, a much brader data base will be necessary to substantiate this assumption. Other processes-especially Iranspon-cannot yet be ruled out as possible explanations for these

Measurements from a completely different continental area are
observations. shown in Table IV. Five air samples were collected in the Arabian Desert in Upper Egypt on 7 and 8 August 1982. In order 10
HYDROCARBONS IN NON.LRBAN ATMOSPHERE

TABLE IV

Hydrociarbon mixing ratos in decest ares in Upper Egypl (average and variance from five sumples collectess on 1982 ?

\begin{tabular}{|c|c|}
\hline Compound & $\underset{\text { (pptx) }}{\text { Mutio }}$ \\
\hline 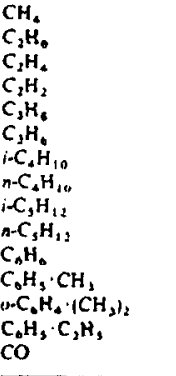 & $\begin{array}{l}1733 \pm 30 \\
2.38 \pm 0.42 \\
0.22 \pm 0.07 \\
0.30 \pm 0.06 \\
0.45 \pm 0.13 \\
0.11 \pm 0.02 \\
0.11 \pm 0.02 \\
0.27 \pm 011 \\
0.09 \pm 0.03 \\
0.09 \pm 0.02 \\
0.19 \pm 0.04 \\
0.22 \pm 0.08 \\
0.03 \pm 0.02 \\
0.05 \pm 0.03 \\
2.48 \pm 34\end{array}$ \\
\hline
\end{tabular}

minimize systematic effects from local sources, the samples were

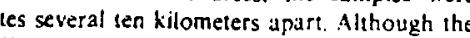
mixing ratios of the different hydrocarbons are quite lou and the trace gas pattern looks somewhat different from that observed a Deuselbach, it is evident that the sampled air masses were to sume extent influenced by anthropogenic hydrocarbon sourcers. This is not particularly surprising since Egypt is a quite densely pupulated country but these results indicate that it is yuite difficult to find continental areas at midnorthern latitudes which are reully frec from

\section{HYDROCARBONS IN THE MARINE ATMOSPHERE}

During a number of cruises of RS Meteor in the Atluntic we made about 100 medsurements of light hydrocarbons. Since the marine environment is much less subject 10 anthropugenic mfluences than 
J. RUDOLPH AND A. KHEDIM

most continental sites, it seems interesting to compare some of these results with the hydrocarbon mixing ratios we found at remote continental sites. In Figure 3 we have plotted the mixing ratios of four different lighe hydrocarbons as function of the geographic
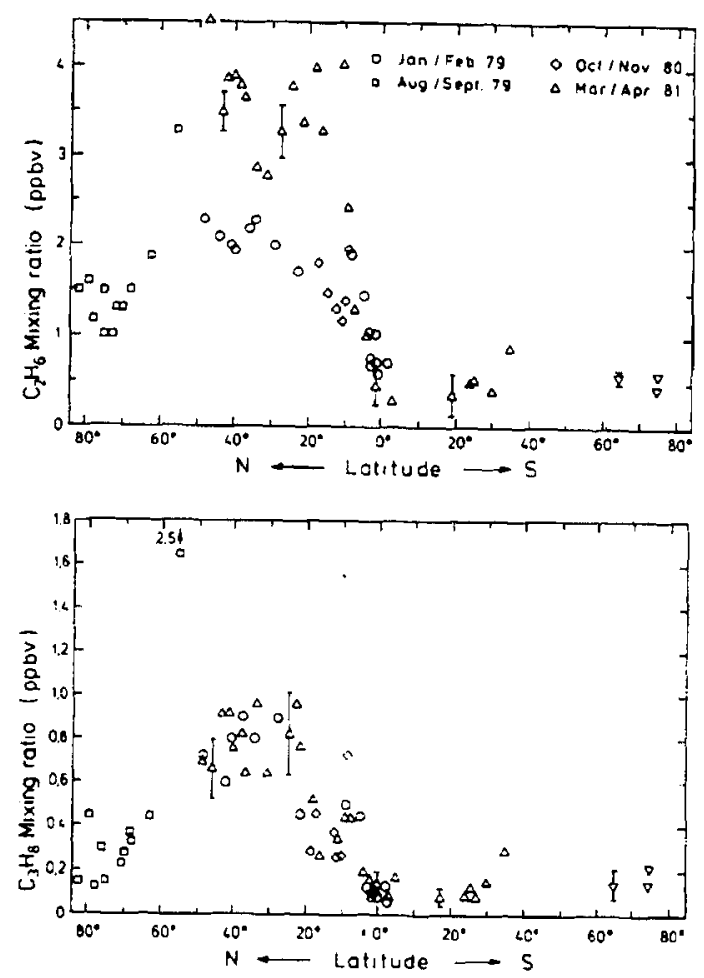

HYDROCARBONS IN NON-LRBAN ATMOSPHFRE
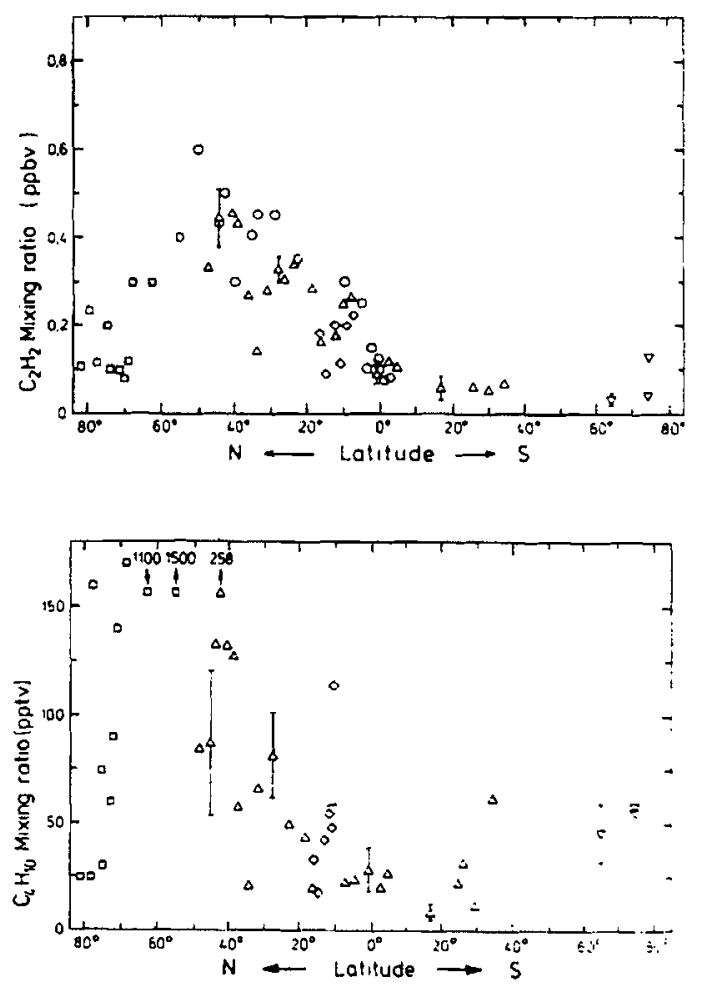

FIGURE 3 Mixing ratios of ethane. acetylene. propane ond whutune wer the

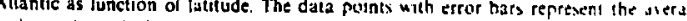

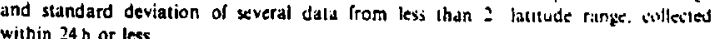


8. RUDOLPH AND A. KHEDIM

latitude. If we compare these measurements with our data from remote continental sites, we can see that for $\mathrm{C}_{2} \mathrm{H}_{6}, \mathrm{C}_{3} \mathrm{H}_{8}$, and $\mathrm{C}_{2} \mathrm{H}_{2}$ the atmospheric mixing ratios over the Atlantic at midnorthern Jatitude are-within the observed scatter-similar to those found over the continents (Tables III and IV). However, $n$-butane (as well as $i$-butane and $n$ - and $i$-pentane which are not sbown here) is significantly less abundant in the marine atmosphere than over the continents. All four of the hydrocarbons shown in Figure 3 show a strong decrease in their mixing ratios between midnorthern latitudes and the equator and the southern hemispheric values are generally lower than the northern hemispheric mixing ratios. This can be explained by the existence of strong-most probably anthropogenicsources for these hydrocarbons at midnorthern laviludes. A quite differen behaviour is observed for propene (Figure 4). The latitudinal profile for propene shows no significant interhermispheric gradient.

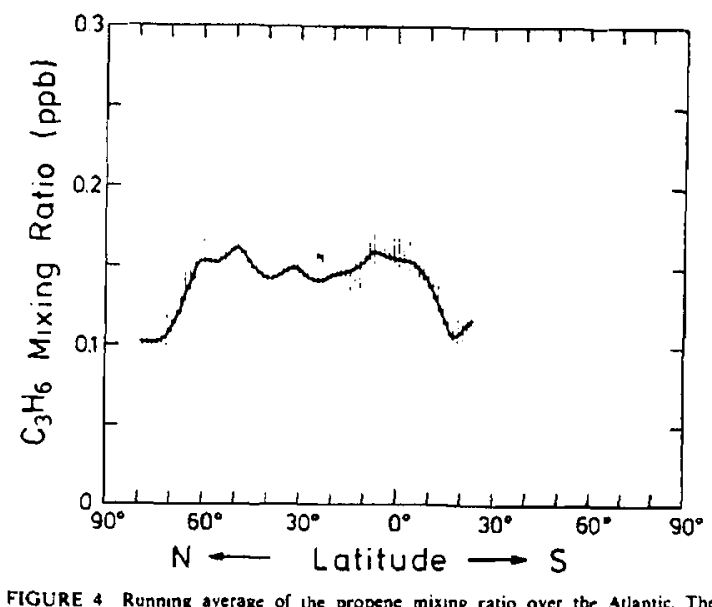

FIGURE 4 Running averaze of the propene mixing ratio over the Allantic. The

verticat bars indicate the error of the averuged propene mixing ratios.
MYDROCARGONS IN NON-LIRHAN AIMUSBPHERE.

With the exception of some more or less random variations, the propene mixing ratio is in the range of $0.12-0.18 \mathrm{ppb}$. These values are comparable to those we observed for remose continental areas. This is ralser surprising if we consider that $\mathrm{C}_{3} \mathrm{H}_{0}$ reacts much laster with OH radicals than $\mathrm{C}_{2} \mathrm{H}_{6}, \mathrm{C}_{2} \mathrm{H}_{2}, \mathrm{C}_{3} \mathrm{H}_{8}$ or $n-\mathrm{C}_{4} \mathrm{H}_{10}$ (see Table I) and consequently will be more rapidly oxjuized in the atmosphere. The most reasonable explanation for this is the existence of significant oceanic sources for propene. Indeed, it has ben shown that propene and ethene are emitted from the oceans at rates which are sufficient to maintain the observed mixing ratios in the marine atmosphere.

\section{VERTICAL DISTRIBUTIONS OF SOME LIGHT}

\section{HYDROCARBONS}

The measuretnents we presented so far were all made on the ground and consequently (with one exception) within the pianetary boundary layer. In this chapter some examples for vertical profiles of hydrocartons up to altiludes well above the almospheric boundary layer are shown. In autumn 1979 we made three nighis with a Do-28 airplane and collected about 25 air samples in an altitude range between $300 \mathrm{~m}$ and $5.5 \mathrm{~km}$. Some of the vertical profiles are shown in Figure $S$. These fights were made over central Germany at $6: 30^{\prime} \mathrm{E}$ $8^{\circ} \mathrm{E} / 51^{\circ} \mathrm{N}-52^{\circ} \mathrm{N}$ on 30 October and 7 November. During all three nights a strong iemperature inversion was observed at about $15 \mathrm{~km}$ altitude. Thus it is not surprising that a steep decrease of the trace gas mixing ratios with increasing ultitude can be observed in the ange from $15-2 \mathrm{~km}$. Ethane and carbon monoxide decrease by factor of $2, \mathrm{C}_{2} \mathrm{H}_{2}$ by a factor of 3 , and $\mathrm{C}_{2} \mathrm{H}_{4}$. the most reactive of the four species by a factor of 10 . The mixing ratios below $15 \mathrm{~km}$ atitude are comparabe to those from remote sites in Germany tsec Table III) above $2 \mathrm{~km}$ the urace gas mixing ratios are extremely lou. The existence of a pronounced inversion layer thus seems 10 infuence the shapes of the vertical profiles considerably. Indecd. I we compare these data with the results of a flight made in March 1981 over the same area we can see significant differences. During this light in March 1981 there was no lemperalure inversion and consequently the urace gas gradients were much less pronounced (see 
J. RUDOLPH AND A. KHEDIM

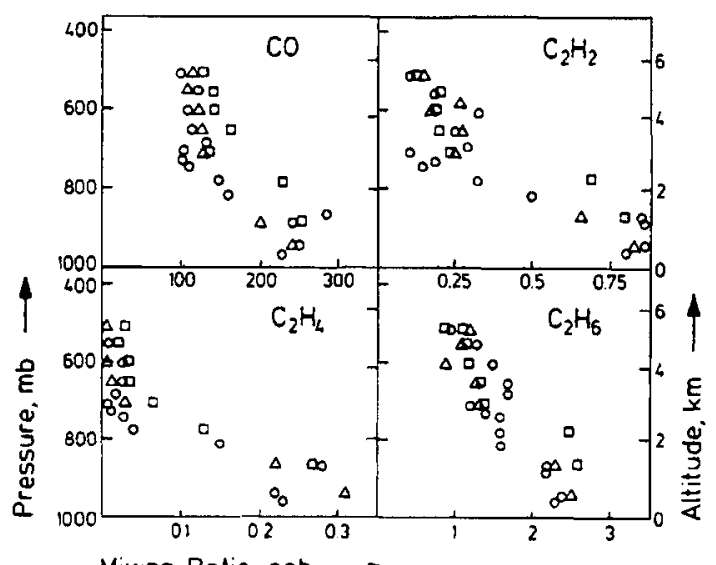

Mixing Ratio. ppb

FIGURE S Vertical profiles of $\mathrm{CO}$ and $\mathrm{C}_{2}$-hydrocarbona oter central Germiny. Triangies: 8 E. 52 N. 10 30.79. 16:00-16:30

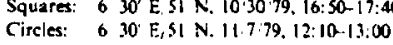

Figure 6). CO. $\mathrm{C}_{2} \mathrm{H}_{6}$. and $\mathrm{C}_{2} \mathrm{H}_{2}$ show only a very weak decrease in mixing ratios with incrcasing altitude. Only for $\mathrm{C}_{2} \mathrm{H}_{4}$ we can observe iderably elevated mixing ratios al lower altitudes.

\section{CONQCLUSIONS}

Light and medium molecular weight hydrocarbons are present in the remote troposhere at low but not negligible mixing ratios. Due to their relatively high reaction rate constants with $\mathrm{OH}$ radicals in the atmosphere the non-methane hydrocarbons may significantly affect the photochemistry of the remole atmosphere.

HYDROCARBONS IN NON-URBAN ATMOSPHERE

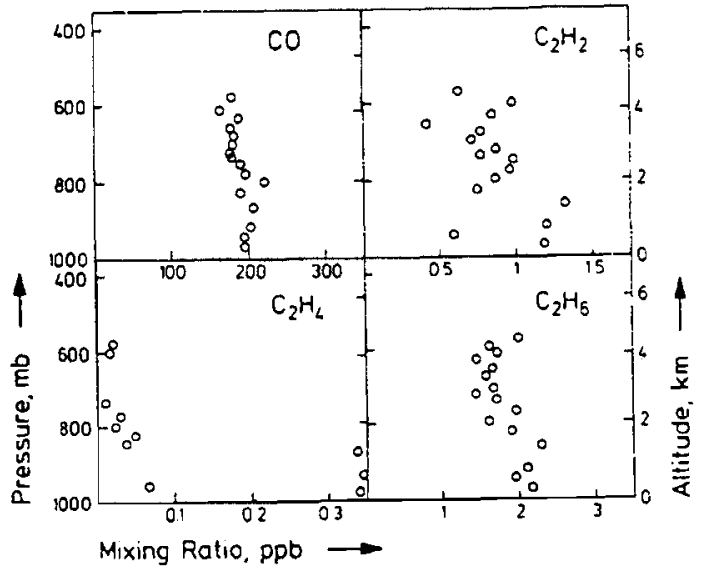

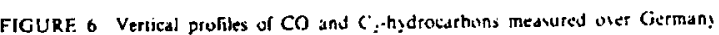
22 March 1981. 14:30-15:30.

For a given area the atmospheric mixing ratios of the sarious hydrocarons depend strongly on horizontal ind vertical urunspo Even in quite remole places the hydrocarbons show a considerable Everiability In general the more reaclive species show is fust decrease with dereasing influence of anthropugenic sources than the less reative hydrocirbons such as $\mathrm{C}_{2} \mathrm{H}_{0} \mathrm{C}_{2} \mathrm{H}_{2}$ or $\mathrm{C}_{2} \mathrm{H}_{3}$ The latter we ave more or less well defintd background niking ras these mu considerable systematic latitudinal dependence. Howertr. these mimo stable compounds only have a limited importanse for the almose pheric chemistry over remole areas. For these areas reactive species with local sources can be considerably more important. e.z. Wthere

The presented picture of the distribution of non-methane hydrocarbons is far from being complete. Neither wover our data for all kinds of remote fexations nor is the list of hydrociartons complete 


\section{J. RUDOLPH AND A. KHEDIM}

Nevertheless, the presented data prove that the non-methane hydrocarbons are an important part of the chemistry of the atmosphere not only in polluted areas but also in the non-urban troposphere.

\section{Acknowledgement}

Part of this work was supported by the German Ministry of Science and Technology.

\section{References}

1. U. Schmidt, A. Khedim, F. J. Johner, J. Rudolph and D. H. Ehhalt. Preprint volume: Second Symposium on the Composition of the Nonurban Troposphere, May 25-28, 1982, Williamsburg, VA (American Meteorological Saciety, Boston, MA), pp. 52-55.

2. R. A. Duce, V. A. Mohnen, P. R. Zimmerman, D. Grosjean, W. Cantreels, R. Chatfield, R. Jaenicke, J. A. Ogven, E. D. Pellissari and G. T. Wallace, Rev. Geophys. Space Phys. 21, 921 (1983).

3. R. F. Hampson and D. Garvin (eds.), Reaction Rate and Photochemical Data for Atmospheric Chemistry, National Bureau of Standards Special Publication 513 (U.S. Government Printing Office, Washington, D.C., 1977).

4. J. Rudolph and D. H. Ehhalt, J. Geophys. Res. 86, 11959 (1981).

5. K. Sexton and H. Westberg, Atmospheric Environ. 18, 1125 (1984).

6. A. Volz, D. H. Ehhalt, R. G. Derwent and A. Khedim, Messung lon atmosphärischem ${ }^{14} \mathrm{CO}$ : eine Methode zur Bestimmung der troposphärischen $\mathrm{OH}$ Radikalkonzentration. Berichte der Kernforschungsanlage Jülich. Jül 1604, Jülich 1979. pp. 58-59. 